\title{
The Implementation of Disaster Resilient Village Program (Study in Tinjomoyo Village, Semarang City)
}

\author{
Adib Hermawan and Budi Pramono \\ Republic of Indonesia Defense University (RIDU)
}

\begin{abstract}
The government has responsibility in disaster management and the community become spearhead in the implementation. The community based disaster management policies were made in Disaster Resilient Village program since 2017 in Tinjomoyo Village, Semarang City. This research purpose was to analyze the implementation and effectiveness of a disaster resilient village program in Tinjomoyo Village and analyzing the affecting factors. This research used descriptive qualitative research methods. This study results indicated that based several aspects of program achievements in disaster resilient village related to Head Rule of National Agency for Disaster Management on General Guidelines of Disaster Resilient Village, the Tinjomoyo Village score was 33 and categorized as First Disaster Resilient Village, with the objective goals of 55\%. The community preparedness based on program objectives was $58 \%$. This means that the program can achieve some of stated objectives. The interviews results showed that Decree of Village Head on Disaster Resilient Village was an alternative strategy with top priority to support the Disaster Resilient Village program. The conclusion was the implementation of disaster resilient village program in Tinjomoyo Village is not optimal because there is no legality to establish a Resilient Village Program and alternative strategies priority to support the Resilient Village Disaster program in Tinjomoyo Village is issuing a Decree of Village Head related to establishment of Disaster Resilient Village.
\end{abstract}

Keywords: Implementation, Preparedness, Resilient Village Disaster Resilient Village Program.

DOI: $10.7176 /$ PPAR/11-2-02

Publication date:March $31^{\text {st }} 2021$

\section{INTRODUCTION}

Disaster is real non-military threats. It can disrupt national security stability. Disasters come from domestic and abroad. Disaster has the potential to cause chaos, even devastate an area if the community does not have the capacity to deal with disaster. Therefore the role of government, community and entrepreneurs is also very necessary in Disaster Management. Quick and appropriate handling can reduce and even eliminate risks, losses or victims. It will support the stability of national security. Every person has the right to get social protection and a sense of security, especially for disaster prone community groups. Every community is obliged to maintain a harmonious social life, maintain balance, harmony and preservation of environmental functions. Law number 24 year 2007 article 4 on Disaster Management explains government, community, and private institutions have obligation and responsibility to work together in disaster preparedness. The Law of Republic of Indonesia Number 24 of 2007 on Disaster Management stated that the change from management paradigm towards the mitigation paradigm, and the development paradigm, community empowerment must be improved to better know about the disasters and characteristics of each region from disaster threat.

Data from Regional Disaster Management Agency in Tinjomoyo Village shows a landslide in 2015 at RW IV with a total of 5 RTs and a population of 915 people. A landslide at RT.02 / 04 due to river collapse during heavy rain. There were 4 landslide locations in 2016 at RW V with 7 RTs with total 1,729 inhabitants. Landslides at RT 04, RT 05 due to large trees fallen in Gombel Lama. The Tinjomoyo Village has slope of 25\% and $37.78 \%$, a hilly area with a $15-40 \%$ slope conditions (0-2\%). Landslide conditions at RW V are caused by human activities to cut trees. This is indeed used as one of logging area. Data of Regional Disaster Management Agency in Semarang City 2018 shows that characteristics of landslide location have similarities with villages in Banyumanik Subdistrict, especially Tinjomoyo Village. Regional Disaster Management Agency release data for Semarang City to shows the rainfall in Banyumanik District is also relatively high with an average of 2500-3000 $\mathrm{mm} /$ year.

In addition to physical conditions, human-related factors in land usage also affect the level of landslide vulnerability. The Community-based disaster risk management put the community as an important actor in the main strategy of disaster risk management initiatives to build disaster resilience. It is implemented through the smallest government units to target directly the community in the village. The policy implementation of Disaster Resilient Village program refers Head Rule of National Agency for Disaster Management. The community should participate actively in implementation of disaster management, including the pre-disaster stage, during disasters and post disasters, based on PP no. 21 of 2008 on the implementation of disaster management. Government Regulation No. 21 year 2008 concerning Implementation of Disaster Management stated that the implementation is done through efforts to increase public awareness and capacity in pre-disaster, emergency 
response and post-disaster stages. Communities readiness and alertness to disasters can reduce, prevent and even eliminating the disasters risk. Based on background of problems with disasters phenomenon at global, national and regional levels, as well as the implementation of community-based disaster risk reduction through the Disaster Resilient Village Disaster Resilient Village program in Tinjomoyo village, Semarang, this research focus on the implementation of a Disaster Resilient Village to improve community preparedness of Tinjomoyo Village, Semarang City, with sub-focus of research in question on How the implementation of Disaster Resilient Village program in Tinjomoyo village and the effectiveness of the village program.

\section{RESEARCH METHODS}

This research uses descriptive qualitative research methods to produces descriptive data in form of written or oral words from people involved in the program. Qualitative research put the researchers as the key instrument. The data collection techniques are done by merging and inductive data analysis (Sugiyono, 2014)

The research instrument was a questionnaire containing structured questions that would be answered by informants. The attached instrument is used explore the program implementation and the level of community preparedness. The instruments used are below.

a) Assessment Instrument of Disaster Resilient Village from Head Rule of National Agency for Disaster Management.

b) The Instrument for Community Preparedness from LIPI-UNESCO / ISDR which has been modified by researchers

The data validity in qualitative research methods uses internal validity (credibility) on truth value aspect. The application relates with external validity (transferability), and reliability (dependability) on aspect of consistency, and objectivity (confirmability) on naturalist aspect (Sugiyono, 2014). The validity level of qualitative research is more emphasized on obtained data. This research data shows a significant influence for the success of a study.

Valid data can be obtained by conducting a credibility test (internal validity) in accordance with data credibility test procedure in qualitative research. The types of credibility testing in according to Sugiyono (2014) include the extension of observations, increased perseverance in research, triangulation, discussion with colleagues, negative case analysis, and member checking. Data analysis techniques uses three steps: Data Condensation, Data Display, and Conclusion / Verifications.

\section{RESULTS AND DISCUSSION}

Tinjomoyo Village is located in urban area of Semarang City. The geographic location is Java Sea in north. The topographical conditions is made up of hills, plains and coastal areas, showing the various slope and protrusions. It makes the Semarang area has natural disasters potential. The disaster report at official website of National Agency for Disaster Management shows 192 tornadoes for 1990 - 2018 (DIBI, 2019). Table 1 shows the disaster events based on Regional Disaster Management Agency in Semarang City data for 2018.

Table 1. Disaster Event in Semarang City Year 2018

\begin{tabular}{|c|c|c|}
\hline No. & Disaster type & Number of events \\
\hline 1 & Flood & 36 \\
\hline 2 & Landslide & 82 \\
\hline 3 & Tornado & 5 \\
\hline 4 & Fire & 69 \\
\hline
\end{tabular}

Source: DIBI, 2019

Table 1 shows that the disasters frequency in Semarang City is still quite high. The highest incidents are 82 landslides. It shows Semarang City has high number of disasters and disaster-prone areas. The observations results at Tinjomoyo Village shows following results.

a. Physical Vulnerability. The natural hills conditions are converted as residential areas. The slums conditions and Jatingaleh market are also vulnerable to fire threats.

b. Social vulnerability. Low awareness in education affects the level of their knowledge. The $16.5 \%$ of population did not graduate from elementary school. The Tinjomoyo village is located at route to Jatidiri stadium, it can also be a social threat of football supporters brawl.

c. Economic Vulnerability. The unproductive population of $27 \%$ can cause social problems in Tinjomoyo Village.

d. Environmental Vulnerability. Some residents have low awareness to built settlements in disaster prone areas, such as in hillside areas and water catchments areas. Knowledge and understanding of citizens regarding disaster is not comprehensive.

The several aspects of program achievement level on Disaster Resilient Village indicators in the questionnaire are based on Head Rule of National Agency for Disaster Management on General Guidelines of Disaster Resilient Village. The 60 question questionnaire was given to Head of Disaster Risk Reduction Forum 
and Lurah Tinjomoyo. The "Yes" answers are 33 and "No" answers are 27 items. The score Tinjomoyo Village is 33 included and within category of First Disaster Resilient Village.

The assessment shows several initial efforts in every aspect of Disaster Resilient Village, starting from existence of a village volunteer team in Disaster Risk Management forum with the member of community representatives, a disaster management planning document that will be used as an SOP, and most importantly a systematic effort to increase capacity disaster preparedness and response. These results means the program can achieve some of its objectives and can be continued with improvements based on evaluation done (Tyler, 2011). Interview results shows that an alternative strategy priority to support the Disaster Resilient Village program in Tinjomoyo Village was to fast issuance of a Village Head Decree on the establishment of Disaster Resilient Village. It becomes a protective legal umbrella for all Disaster Resilient Village activities. Based on Head Rule of National Agency for Disaster Management, Disaster Resilient Village decree also encourages the integration of disaster management plans into village development plans. This also encourages funding allocation from the village and private sector if the Disaster Resilient Village program is included in village development plan and protected by a Regulation umbrella from Village Head of Tinjomoyo Village.

\section{CONCLUSIONS AND RECOMMENDATIONS}

The conclusions of this study explain the implementation of disaster resilient village program and effectiveness of disaster resilient village program in Tinjomoyo Village. The implementation effectiveness of disaster resilient village program in Tinjomoyo Village achieves part of the objectives in Disaster Resilient Village indicator value in Tinjomoyo Village, obtaining a score of 33 with a success rate of $55 \%$. It falls into First Disaster Resilient Village category. It relates to no decree related to Disaster Resilient Village program in Tinjomoyo Village, but there have been initial efforts to formulate Disaster Risk Management policy and most important thing is a systematic effort to increase the capacity of community in facing disaster threats

The effectiveness of Tinjomoyo Village Resilient Village Resilient Village Program can be seen from results of interviews with 20 resource informants at $58 \%$ average value of community preparedness. The Disaster Resilient Village program effectiveness is affected by internal and external factors. The interviews results show that alternative strategy priority to support the Disaster Resilient Village program in Tinjomoyo is to make Village Head Decree regarding the establishment of Disaster Resilient Village. This decree becomes protective legal umbrella for all Disaster Resilient Village activities. In accordance with Head Rule of National Agency for Disaster Management, Disaster Resilient Village decree also encourages the integration of disaster management plans into village development plans.

\section{REFERENCES}

Aitsi-Selmi, A., Egawa, S., Sasaki, H., Wannous, C., \& Murray, V. (2015). The Sendai framework for disaster risk reduction: Renewing the global commitment to people's resilience, health, and well-being. International Journal of Disaster Risk Science, vol. 6(2), 164-176.

Aji Prasetyo, dkk. (2013). Penegakan Hukum Tindak Pidana Pembakaran Hutan di Wilayah Kabupaten Kotawaringin Timur. Jurnal Diponegoro Law Review, vol 1(2) pp. 1-10

Anggoro, K. (2003, July). Keamanan Nasional, Pertahanan Negara, dan Ketertiban Umum. In Seminar Pembangunan Hukum Nasional VllI. Denpasar: Badan Pembinaan Hukum Nasional, Departemen Kehakiman dan HAM RI.

Arikunto, Suharsimi. 2006. Prosedur Penelitian Suatu Pendekatan Praktik. Jakarta: PT Rineka Cipta.

Cresswell, W. John. (1994). Research Design: Qualitative And Quantitative Approach. California: Sage Publication.

Data of Regional Disaster Management Agency in Semarang City 2018

Domestic Ministry Regulation No. 46 year 2008 on Organization Guidelines and Work Procedure of Regional distric Management Agency

Dunn N, William. (2000). Public Policy Analysis: An Introduction Second Edition. Yogyakarta: Gajah Mada University Press.

Edward III, George C (edited), 1984, Public Policy Implementing, Jai Press Inc, London-England.

Government Regulation No. 21 year 2008 concerning Implementation of Disaster Management

Gunawan. (2009). Studi Evaluatif Tentang Penanggulangan Bencana Alam: Peran TAGANA Dalam Peningkatan Kesiapsiagaan Masyarakat Untuk Mengurangi Resiko Bencana Alam. Jakarta: P3KS Press.

Indonesia Republic Regulation No. 20 year 2003 on National Education System, Bandung: Fokus Media, 2006.

Irawan, Prasetya (2007). Penelitian Kualitatif dan Kuantitatif untuk Ilmu-ilmu Sosial. Depok: DIA Fakultas Ilmu Sosial dan Ilmu Politik Universitas Indonesia.

Lassa, J., Pujiono, P., Pristiyanto, D., et all. (2009). Pengelolaan Risiko Bencana Berbasis Komunitas (PRBBK). Jakarta: Grasindo.

Law of Republic of Indonesia Number 24 of 2007 on Disaster Management 
Maarif, Syamsul (2012). Menuju Indonesia Tangguh. Makalah Rapat Koordinasi dan Pelatihan Tingkat Nasional Tahun 2012. Jakarta: BNPB, 2012

Pujiyanto. (2012). Analisis Ketangguhan Masyarakat Dalam Menghadapi Bencana Banjir di Pemukiman Bantaran Kali Ciliwung. Program Studi Manajemen Bencana, Fakultas Keamanan Nasional, Universitas Pertahanan.

Regulation of National Agency Head for Disaster Management No. 1 year 2012 on General Guidelines for Disaster Resilient Village

Saldaña, J. (2011). Fundamentals of Qualitative Research: Understanding Qualitative Research. New York: Oxford University Press.

Sugiyono, Metode Penelitian Pendidikan (Pendekatan Kuantitatif, Kualitatif, dan R\&D), Cet. XV (Bandung: Alfabeta, 2014)

Syamsiah, Noorma. (2012). Kesiapsiagaan Masyarakat Dalam Menghadapi Ancaman Gunung Berapi (Studi Kasus di Kelurahan Mulyaharja Kecamatan Bogor Selatan Kota Bogor Provinsi Jawa Barat). Program Studi Manajemen Bencana, Fakultas Keamanan Nasional, Universitas Pertahanan

Winarno, Budi. (2008). Kebijakan Publik: Teori dan Proses. Yogyakarta: MedPress

Wirawan. (2011). Evaluasi (Teori, Model, Standar, Aplikasi, dan Profesi). Jakarta: Rajawali Pers.

\section{ATTACHMENT: TRANSCRIPT INTERVIEW}

\section{Informant Data}

Initial : YK

Position : Section Head of Prevention and Preparedness of Regional Disaster Management Agency in Semarang City

Location : Regional Disaster Management Agency Office at Semarang City

Date : October 20, 2019

\section{Interview result}

Q : $\quad$ What the Disaster Resilient Village that has been the implementation Tinjomoyo Village?

YK: $\quad$ The Disaster Resilient Village program is a series of activities from workshops to better recognize their own environment, develop risk studies, prepare disaster risk reduction action plans, socialization, deliberation, field verification visits, disaster mitigation development, and training to improve technical skills certain. At beginning of program period, it is important to know the profile and initial conditions of target community. It can become a reference in process to facilitate and implementing the KATANA program. The implementation of 2017 Katana program has become government's program in disaster management. It is a form of sustainability of Disaster Prepared Village in Tinjomoyo Village. However, relatively short time is not enough to describe the success of Disaster Resilient Village. There are still many things that must be done by community, government, private sector, and related elements to continue to oversee and improving the Disaster Resilient Village in Tinjomoyo Village which formed in 2017.

Q : What are the barrier factors of Disaster Resilient Village implementation in Tinjomoyo Village?

YK: The barrier factors are low interest of society and younger generation in disaster risk reduction efforts. The socialization invitation to all member of youth groups only attract a small number and lack of budget allocation from village, specifically for Disaster Resilient Village program.

Q : $\quad$ What are the supporting factors of Disaster Resilient Village implementation in Tinjomoyo Village?

YK : The involvement of related parties is very important. Their involvement in planning, implementation and monitoring of rebuilding process was better, including local governments, local communities, experts and academics, media, and private sector in Disaster Resilient Village program become factors of program's success. Planning for involved parties are made together with all stakeholders who play a role in efforts to improve community preparedness. In addition, an increase in commitment in form of additional aid funds, addition of trained personnel, improvement of facilities and infrastructure for mitigation, as well as research and studies aimed at reducing the impact of disasters are also needed. The involvement of private sector is limited to formation of Disaster Risk Reduction Forum, which involves UNIKA and Gajah Mada Radio, but there is no involvement in structural and non-structural mitigation activities such as socialization, technical training, and simulation.

\section{Informant Data:}

Initial : DM

Position : Tinjomoyo Head

Place : Village Hall of Tinjomoyo Village, Banyumanik District

Date : October 23, 2019 
Q : $\quad$ What the Disaster Resilient Village that has been implemented in Tinjomoyo Village?

DM: The landslide incident in 2015 closed access road and damaging several houses. It was a bitter experience for community of Tinjomoyo Village in facing disasters. That experience is still imprint up to now, especially in hills areas. Therefore Disaster Alert Village program was formed from Ministry of Social Affairs and Disaster Resilient Village was a continuation of Disaster Alert Village program. This program should improve the comprehension of potentials within community to be able to recognize and deal with threats, empower and increase capacity and minimize vulnerability to reduce risk independently, establish collaboration and maximize synergies to release dependency to create resilience in Tinjomoyo Village. For more detailed information, please ask directly to Head of Disaster Risk Reduction Forum in Tinjomoyo Village, Mr. Supardi.

Q: What are the supporting factors for the implementation of Disaster Resilient Village program in Tinjomoyo Village?

DM: $\quad$ Supporting factors for implementation of Disaster Resilient Village program in Tinjomoyo Village are cooperation from all parties, from Regional Disaster Management Agency, Community Organizations, including Unika and Gajah Mada Radio FM when taking part in formation of a Forum on disaster risk reduction, in addition to location of Tinjomoyo Village those in urban areas and who have strategic access make it easy to reach by parties from outside the village, both from private and related agencies, to contribute in Disaster Resilient Village program, such as during a landslide in Tinjomoyo in 2015, assistance from Regional Disaster Management Agency and private sector such as Gajah Mada Radio FM, Unika, Unnes, and Undip were quickly channelled because Tinjomoyo Urban Village was very easy to reach.

Q: What are the inhibiting factors for the implementation of Disaster Resilient Village program in Tinjomoyo Village?

DM : The inhibiting factors for the implementation of Disaster Resilient Village program in Tinjomoyo Village is the absence of a decree on Disaster Resilient Village from Semarang City government to Tinjomoyo Village government. There is no legality as a basis for implementation of a disaster resilient village program in Tinjomoyo Village. It also causes the lack of funding, especially from private sector that goes in to work together in disaster resilient village activities. The low assistance time from Regional Disaster Management Agency in Semarang City to Disaster Risk Reduction Forum, Disaster Management Plan and community, it would affect the quality of people or stakeholders in Tinjomoyo Village. During this time the Regional Disaster Management Agency is still lacking in monitoring and evaluation, it also become inhibiting factors for the implementation of Disaster Resilient Village program in Tinjomoyo Village.

Q : $\quad$ Why the decree on Disaster Resilient Village program has not been issued?

DM : There is still confusion about who issued the decree, whether from village, sub-district or city government.

\section{Informant Data:}

Initial: SP

Position : Head of Disaster Risk Reduction Forum in Tinjomoyo Village

Place : Village Hall of Tinjomoyo Village, Banyumanik District

Date : October 23, 2019

Q : $\quad$ Is there a decree related to the formation of Disaster Resilient Village program in Tinjomoyo Village?

SP: $\quad$ It seems does not exist, but there was a decree issued by Tinjomoyo Urban Village for disaster risk reduction forum on the Disaster Risk Reduction Forum establishment in Tinjomoyo Village.

Q : $\quad$ Why is there still no decree on establishment of Disaster Resilient Village?

SP : $\quad$ It is still ambiguous which party issued the decree

Q : $\quad$ In accordance with Head Rule of National Agency for Disaster Management, The decree can be issued by Head of Village.

SP : $\quad$ I see. I will tell it to village head.

Q : $\quad$ How is the formation of Disaster Risk Reduction Forum in Tinjomoyo Village?

SP: $\quad$ It begins with initial and continued socialization by Regional Disaster Management Agency about disaster resilient villages then followed by Forum Group Discussion activities involving community organization from LPMK, BKM, PKK mobilization team, PKK RT and RW, Mosque Youth Association, RT / RW forum, Babinsa, Babinkamtibmas, Disaster Alert Village in Village Tinjomoyo, Village Health Forum, Dawis, Satkom, Karang Taruna, Garbage Bank Mudika, and Banser / Ansor have formed the Disaster Risk Reduction Forum and Disaster Management Plan at Tinjomoyo Village level. Both forums received assistance from Regional Disaster Management Agency facilitators to implement and create working groups related to disaster resilient village programs. 
Q : $\quad$ Has the disaster risk reduction policy at village level involved all stakeholders?

SP: $\quad$ Yes it has. The formation of Disaster Risk Reduction Forum and Disaster Management Plan involves various elements of society including LPMK, BKM. RT RW, PKK, FKK, Dawis Group, Unika, Gajah Mada Radio, Disaster Alert Village, Community Protection, Karangtaruna, Babinsa, Babinkamtibmas, Garbage Bank, Mudika, Mosque Youth Association, Pancasila Youth, Banser / GP Anshor, Satkom, Rapi and PSKM

Q : $\quad$ What is the function of Disaster Risk Reduction Forum in Tinjomoyo Village?

SP: $\quad$ The forum is facilitated by Regional Disaster Management Agency facilitators to implement and creating working groups related to Disaster Resilient Village programs which will later create disaster risk mapping and disaster management plans.

Q : $\quad$ What is the planning for disaster risk reduction in Tinjomoyo Village?

SP: $\quad$ These plans contain "who has what". It is community commitment in efforts before and when a disaster. The drafters are managers / decision makers from elements of community involved. The planning made by Disaster Risk Reduction Forum in Tinjomoyo village consists of Disaster Management Plan, Community Action Plan (RAK) and Contingency Plan. The preparation of Disaster Management Plan, RAK and Contingency Plan in Tinjomoyo Village was prepared through the participation of various elements of community and was adjusted to needs of Disaster Resilient Village. For example, we focus on landslide threats as a risk reduction because Tinjomoyo area has landslides threat. Detail about the Disaster Management Plan, RAK and Contingency Plan can be seen in village resilient document of Tinjomoyo Village.

Q : $\quad$ Has there been a decree on formation of Disaster Risk Reduction Forum? and who authorizes it?

SP: $\quad$ There is a decree and it is approved by Tinjomoyo Head.

Q : $\quad$ Is there an funds allocation from village for Disaster Resilient Village program?

SP: $\quad$ All activities are still funded by Semarang City Regional Disaster Management Agency, but there is a non-governmental fund called the pre-disaster savings village granary. The funds are actually prepared for emergency response activities but in practice it can still be used for forum meetings or capacity building activities for volunteers and Public.

Q : $\quad$ What are the programs that have been run by Disaster Risk Reduction Forum and Volunteer Forum?

SP: $\quad$ From the 2017 formation of Disaster Resilient Village program, Tinjomoyo Village has done 2 socialization sessions on formation of disaster resilient villages. The results of socialization provided debriefing and knowledge to Disaster Risk Reduction Forum members regarding disaster resilient villages. There was one landslide simulation on 26 April 2018 as well as commemorating national preparedness day, elderly gymnastics, capacity building for volunteers and women / vulnerable groups, and community service activities in RW 4 for construction of flood retarding flood places in 2019.

Q : Has there been cooperation with other parties for disaster risk reduction activities in Tinjomoyo Village?

SP: $\quad$ Yes, the formation of Disaster Risk Reduction Forum involved private parties such as Radio Gajah Mada and Unika but it has not continued for further activities such as simulations, strengthening volunteers, etc. It will be possible to continue to establish partnerships with private sector because the private sector is very important in disaster management. For example, emergency aid comes from private sector. Therefore, their contribution should not only during the emergency response but also in effort to reduce the risk of disasters before a disaster occurs.

Q : $\quad$ Is there an early warning system in Tinjomoyo Village

SP: $\quad$ Not yet, the information delivery still uses the traditional system that is the gong and mosque speakers.

Q : $\quad$ Is there an evacuation route in Tinjomoyo village?

SP: $\quad$ Yes it is, it seems that an evacuation guide board has not been installed, being socialized in community forums.

Q : $\quad$ What factors to support and hinder the implementation of Disaster Resilient Village program ?

SP: The supporting factor is the compactness of community members who work together in a meeting, outreach and simulation event. But younger generation participation is not maximal in the activities because there are still many who go to school and are busy with their respective activities. The support from UNIKA and Gajah Mada Fm was also helpful and was a good start when the formation of Disaster Risk Reduction Forum and of course in future there would be continued cooperation from such private parties. The inhibiting factors include the absence of legal decree regarding the establishment of Resilient Village so that it affects other aspects, especially the low funding from both the government and private sector.

\section{Interpretation}

Legislation. Tinjomoyo Urban Village has a policy orientation towards disaster risk mitigation in their area with establishment of Disaster Risk Reduction Forum and Disaster Management Plan. Indeed, Disaster Resilient 
Village in Tinjomoyo Village has not been officially documented by decree on Disaster Resilient Village program, but that does not mean that implementation of the program is not a priority in village development.

Planning. Tinjomoyo Village has prepared a Disaster Management Plan, Community Action Plan (RAK) and Contingency Plan through Disaster Risk Reduction Forum and Disaster Management Plan. The Disaster Management Plan is a plan prepared by working group of Disaster Resilient Village to represent the community in a participatory manner, it contains a 5 year disaster management plan. RAK is a detailed plan for disaster risk reduction activities by disaster management stakeholders in the village, it contains a brief description of activities (number, activities, actors, location, budget, source of funds, and location of implementation). This plan is a breakdown of Pre-disaster program in Disaster Management Plan which takes effect in 3 years and planned as a legal document for development planning in the village, government and nongovernment program schemes at village level. The Village Contingency Plan indicates the readiness of all disaster management stakeholders in the village to face certain disaster threats that will occurred.

There is no special funds allocation for disaster risk reduction efforts because funding for DRR efforts still relies on district government of Regional Disaster Management Agency in Semarang City. However, community has an initiative to collect non-governmental funds in term of "pre-disaster savings village granary". It can be used at any time both in pre, emergency and post-disaster response.

Capacity Development. The training was provided in form of socialization, simulation, and debriefing for Disaster Risk Reduction Forum members, Disaster Management Plan forums and the community. Capacity building activities implementation have also involved vulnerable groups such as the elderly and women in various activities such as elderly gymnastics activities, and landslide disaster simulations.

Implementation of Disaster Management. Simulation activities (landslide rehearsal) have been done. Evacuation and rescue routes are available in Tinjomoyo area, but they have only been socialized and the evacuation route board have not yet installed. The available early warning system is still traditional. Physical mitigation is not yet a village development plan, but the community has made efforts to reduce their respective disaster risks, one of them through environmental service, reforestation, making flood retarding slopes, strengthening slopes with sacks burlap and others, individually or in mutual cooperation.

\section{Researcher documentation.}
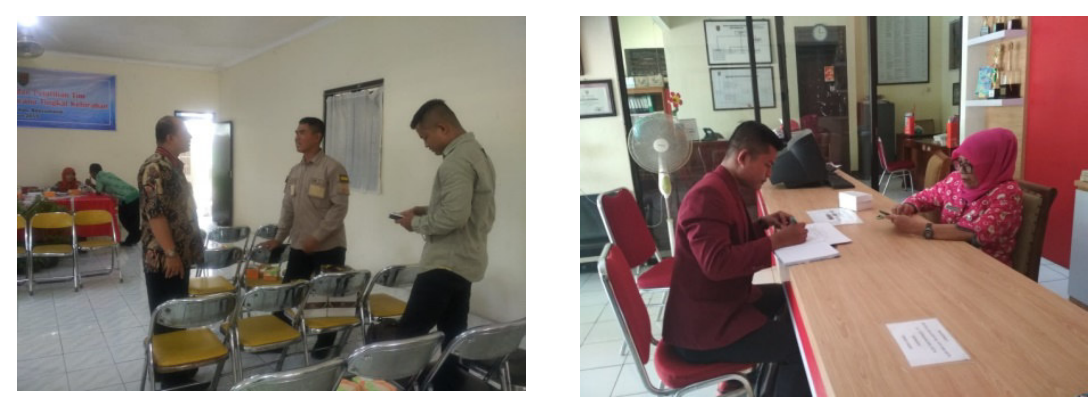